\title{
Political and Familial Repercussions of Naxalism in Lahiri's The Lowland
}

\author{
Manish Kumar Ishan \\ Research Scholar \\ Brabu Bihar University \\ Muzaffarpur, Bihar, India \\ ishanmanish@gmail.com
}

\begin{abstract}
This research article, Political and Familial Repercussions of Naxalism in Lahiri's The Lowland seeks to examine Jhumpa Lahiri's The Lowland as a saga of two Bengali brothers; Subhash and Udayan Mitra, who belong to a middle-class family in the light of Naxalite movement. The narrative of The Lowland purports to depict how the tenderest of ties are torn asunder and the absence of loved ones haunts the subconscious mind of the affected characters in the novel. At the same time, Lahiri questions the politics of nationality with both pathetic desperation and revolutionary zeal. It examines the impact of Naxalite movement on socio-political life of the time, which later turns into a complete fiasco. It shows how Lahiri's depiction evokes our feeling of familial responsibilities and we become dejected by devastating stories of passion and indifference. Above all, it tries to analyze Lahiri's sense of history which is not as insightful as her grasp of human heart that are palpable in her other works.
\end{abstract}

Keywords: Naxalite Movement, Revolution, Assassination, Family. 
Jhumpa Lahiri's works mainly deal with the existential issues of Indian immigrants in America and portray their problems related to identity and representation. Her fiction is based on the memories of her parents as well as her own which formed after her frequent visits to India. She admits:

When I began writing fiction seriously, my first attempts were, for some reason, always in Calcutta, which is a city I know quite well as a result of repeated visits with my family... (Das 176).

Lahiri's preoccupation with issues of Indian diaspora, identity crisis, displacement, exiles and cultural alienation often categorizes her as an immigrant author, but she does not support this opinion. "I don't know what to make of the term", she told The New York Times, "Given the history of the United states, all American fiction could be classified as immigrant fiction." She is not desirous of projecting herself as an immigrant writer hence she takes it as a challenge in The Lowland where she tries to break her stereotypical image of immigrant author and highlights the serious issue of Naxalite movement of India.

The Lowland is a tale of two brothers during the period of Naxalite movement of West Bengal in late 60's. Naxalite movement has been used as a motive in the novel. Though the entire plot revolves around the Naxalite movement, the writer is least concerned with the main motive of movement. She weaves her story around it, but she appears to be less interested in diving deep into the root cause of this uprising. Her lack of literary sensibility is occasionally perceptible in the novel.

A comparative study of Lahiri's The Lowland and Mother 1084 (originally a Bengali work; Hajar Churashir Maa by Mahasweta Devi) gives us an opportunity to analyze Lahiri's approach in this novel that is somewhat different from Mother 1084. Unlike The Lowland, Mahasweta Devi's Mother 1084 delineates Naxalite Movement with literary maturity where she traces the cause of disillusionment of Bengali youth with existing social and power 
system. At the same time she shows imaginative curiosity about Naxalite Movement and she has sympathy for the cause that motivates Brati, Sujata's (protagonist) younger son, to join this movement that Lahiri fails to present in The Lowland.

Naxalite Movement was a revolutionary social movement of peasants and have-nots of the society. It occurred in 1969 with a left wing peasant uprising in the Naxalbari area in the district of Darjeeling, in the northern part of West Bengal. Two important figures associated with this movement were Charu Mazumdar and Kanu Sanyal. They developed new military strategy and gureilla warfare to boost the peasant struggle against the rich and influential landlords. But it was later quelled by the existing government. Naxalism is based on the ideology in which the end justifies the means. The ideology of Naxalism has been borrowed from Mao Zedong's concept of communist theory who was a leader of the People's Republic of China. Naxalism follows the principle of communist theory that believes liberation from the oppression of imperialism is possible only through armed revolution. In this way, members of Naxalite Movement glorified violence and were injured to great loss of life.

The narrative of The Lowland is centered on the grounds of Tollygunj club, a British built country club in Kolkata, West Bengal. Tollygunj club stands as a memento of British colonial rule in India. The club walls have been erected in such a way that it prevents the encroachment of the poor inhabitants of Tollygunj inside the club. In the very beginning of the novel, the novelist succinctly delineates the lives of poor people of Tollygunj and the luxurious lifestyle of elites of the club. She presents two worlds which are poles apart and this sets a platform for her narrative. The novel discusses the lives of two brothers; Subhash and Udayan who share an unusually close bond in terms of their uncanny similarities and their voices. But Lahiri beautifully and diligently depicts the differences between the two: 
He (Udayan) was blind to self-constraints, like an animal incapable of perceiving certain colors. But Subhas strove to minimize his existence, as other animals merged with bark or blades of grass (Lahiri 11).

The novelist describes how Udayan made a shortwave radio himself as he wanted more news of the world. The radio here plays a crucial role in Udayan's life that serves the role of a window to the external world to a typical Bengali youth grown up with "plates of streaming rice and dal and matchstick potatoes" (7). On other occasion, while peeping into the club through its fence, Subhash and Udayan came across a policeman who started beating Subhash. This evoked Udayan's anger and he protested against the action of the police. Lahiri quotes thus:

Stop it, Udayan shouted to the policeman. He crouched next to Subhash, throwing an arm across his shoulders, attempting to shield him(9).

In this way, Lahiri aptly describes Udayan's revolutionary instinct, where he truly appears as a fitting recruit for Naxalite Movement. In the beginning chapters of the novel, Lahiri vividly portrays the political scenario of West Bengal and her authorial narrative prepares the readers for the final catastrophe in Udayan's life. She beautifully illustrates the solidarity of Bengali youths for oppressed class of the society, which finds expression through their participation, in the Naxalite Movement in the form of Udayan. Prior to the revolt of Naxalbari, people of Bengal thought that the establishment of a government of workers and peasants would sort out all their problems and it would ensure better life for them. But things do not go in their own way:

The united Front hadn't backed the rebellion. Instead, in the face of dissent, Jyoti Basu, the home minister, had called in the police. And now Ajay Mukharjee had blood on his hands... The same week, authorized by the West Bengal cabinet, five hundred officers and men raided the region. They searched the mud huts of the poorest villagers. They captured unarmed 
insurgents killings them if they refused to surrender. Ruthlessly, systematically, they brought the rebellion to its heels( 22$)$.

This event drew the attention of educated and unemployed students of colleges and universities of Kolkata. The students of different universities of Bengal thought that their involvement in this protest would bring desired results. Massive protest and uprising shocked both, Subhash and Udayan, but Udayan was more swayed by this incident. Later Udayan even tried to involve his brother in this movement in which he was participating covertly. But Subhash had his own ambition to fulfill and he was also skeptical about the main purpose of such mass uprising. Later we come to know that Udayan actively participates in Naxalite movement led by Charu Mazumdar and Kanu Sanyal. The novelist's authorial narrative in The Lowland reveals her approach and attitude towards these revolutionaries when she describes Naxalites' misguided motives and practices in details:

They intimidated voters, hoping to disrupt the elections. They fired pipe guns on the streets. They hid bombs in public places, so that people were afraid to sit in a cinema hall, or stand in line at a bank.

Then the targets turned specified. Unarmed traffic constables at busy intersections. Wealthy businessmen, certain educators, members of the rival party, the $C P I(M)$. The killings were sadistic, gruesome, intended to shock... (87).

To tackle these serious situations, the government of state had renewed an old law which "had been created by the British to counter independence, to cut off its legs" (88). The ironical note of the novelist is apparent here.

Thus readers are made aware of Naxalites' little understanding of ideology that they blindly followed; they did not gauge the importance of mass mobilization and committed serious crimes while pursuing their version of revolution. During the participation in Naxalite movement, Udayan comes across a college girl named Gauri. He develops a romantic 
relationship with her which culminates in marriage. In the latter part of the novel we come to know about Gauri's role in Naxalite uprising and how Udayan uses her in carrying out his secret missions. Udayan's brother, Subhash finds himself unable to fully relate to the movement. Subhash leaves India to pursue his doctoral studies at a university in Rhode Island in America. Their ideological differences create an irreparable chasm in their relationship and novelist's intention is crystal clear in her statement:

I thought it would be much more interesting for the story to set up a contrast between these two brothers, to have one involved politically and one to be aloof, because I think it creates an inherent tension between the brothers", Lahiri says, "And I wanted to show how the movement could seduce one while leave another indifferent (Neary).

Lahiri does not seem much interested in Naxalite politics, its motives, success or failure. Readers gradually become familiar with this fact between the pages of the novel. She is less bothered about the ethos and spirits of the political culture that she chooses to depict in her novel. Readers further interest in Naxalite movement is quelled after Udayan's sudden death in the novel which comes in the form of a telegram to Subhash; 'Udayan killed, come back if you can'. We come to know about Udayan's assassination in the form of Gauri's narration and the writer describes her death scene succinctly. We are informed "There was the clean sound of the shots, followed by the sound of crows, coarsely calling, scattering”(105).

The assassination of Udayan by paramilitary forces astonishes us and this scene of the novel cause disillusionment with Naxalite movement in the minds of its readers. Finally, at the end of the novel readers are told about the Udayan's involvement in the execution of an unarmed policeman with his comrades. Before that readers are engrossed in the consequences of Udayan's assassination on members of his family especially his wife Gauri and daughter Bela. Later we come to know that Udayan was not solely responsible for policeman's 
assassination but he played an important role in this killing. Thus the narrative deals with two murders: the assassination of a policeman by Udayan and his comrades, and Udayan's own assassination by police forces. The depiction of Udayan's assassination lacks author's sympathy. The way Lahiri depicts Udayan's assassination, appears as a novelistic indictment in her narrative. Lahiri fails to express her sympathy for Udayan and youth like him who was not fully aware of the consequences of their contribution in Naxalite movement and find themselves in an emotional limbo. Lahiri's narrative does not offer a sensible reading of the Naxalite movement, she describes Udayan and comrades as 'they were symbols of brutality, trained by foreigners'. ( 337)

Readers notice a shift in narration after Udayan's assassination by the paramilitary forces. The political upheaval almost disappears in the novel and readers' attention is drawn towards Subhash and his role in his family, at the same time we notice a drastic change in the character Gauri's. Main characters are seen to be much preoccupied with their personal interests and motives. Meanwhile, we find few references of politics, to the civil right movement and the antiwar demonstrations but the major part of the novel especially its middle section is crammed with personal lives of Udayan's family members. Here we find a glimpse of lives of Subhash, Gauri (now Subhash's wife), and Bela (Gauri's daughter by Udayan). After a span of almost forty years, Gauri is seen to be again interested in the politics, when she comes across news related to 'Naxalite activities in various parts of India' in journal on internet. Hence, once again novelist tells us about latest developments of Naxalite activites:

Once in a while Gauri notices a piece in American papers mentioning Naxalite activity in various parts of India, or in Nepal. Short pieces about Maoist insurgents blowing up trucks and trains. Setting fire to police camps. Fighting corporations in India. Plotting to overthrow the government all over again (275). 
The novelist's lack of insightfulness can be easily noticed in her characters. Her characters are flat and static. We find that portrayal and treatment of the character Gauri seems to be another loophole in her literary sensibility. At the outset of the novel, Gauri appears remarkably interesting character whether we look at her life experiences, her interest, her relationship with Udayan, her protest against the expectation of his family in the form of marriage or her role as an accomplice in the Naxalite movement. Gauri's character becomes more opaque after marrying Subhash when she moves to Rhode Island. She resists all her familial duties that she was supposed to perform, as a mother and as a wife. She physically and emotionally withdraws herself from daughter and her husband. Thus readers are forced to think about the character Gauri for her indifference. This development of Gauri's character makes us apathetic towards her and readers do not find a suitable reason for her exclusion from the author's sympathy. Besides Gauri, there had been much scope for the development of other characters as well which remains unaccomplished in the novel. According to New York Times review:

Apart from Gauri, compellingly opaque at moments, the characters seem frozen into typesSubhash (dull but capable), Udayan (charismatic but irresponsible), and Bela (the rebel with a tattoo on her ankle and a compost bin in the backyard).

The novelist's approach towards Gauri's intractable behavior seems to be justified in the later section of the novel. We come to know that Gauri was also one of the accomplices in the assassination of the policeman in which Udayan was also a culprit. This implicit authorial voice justifies her eccentricity and thus she was doomed to face such a secluded and alienated life after Udayan's death. The writer is not willing to scot her free from her intangible crime. Udayan appears as an idealist person in the novel. He was deeply moved to see poverty in the villages of Bengal, but his own actions do not justify her position in the family. He also does something so ugly for the cause that he feels he has lost the moral right to raise a child. While 
dull and worthy Subhash cares more about his parents than the peasants but he, in turn, proves a loving father-bringing up Udayan's daughter as his own after his Naxalite brother is captured and shot by the police.

The Lowland deals with politics of Bengal in late 60's. We expect from the novelist to depict the political incidents through the eyes of the character and by their activities. However, in the text, Naxalite movement has been presented mainly through the novelist's indictment. Lahiri does not provide a humanized reading of the Naxalite movement and political is explored through the intimate life experiences of the characters. It shows that the novelist does not have experimental knowledge of the movement. Characters in the novel also do not live up to the expectation of its readers. Authorial intrusion in the text often does not allow us to relate the motivations behind Udayan's participation in the Naxalite movement. After going through the pages of the novel, we feel that novelist's lack of literary sensibility can't be held responsible out and out because it is really not possible for an expatriate writer to present a true picture of such a movement which she does not have firsthand experience. Apart from all these textual imperfections The Lowland provides a window to the international readers to the Naxalite movement of India that was self defeating in its tactics and the lack of coordination among its members and the writer has beautifully presented that borrowed ideology can't fulfill the true motto of any revolution. 


\section{References}

Lahiri, Jhumpa. The Lowland. Random House India, 2013.

Devi, Mahasweta. Hajar Churashir Maa. Kolkata:Karuna Prakashani, 1974.

“Jhumpa Lahiri: By the Book". The New York Times, 5 Sept. 2013, web 21Aug. 2019

Neary, Lynn. "Political Violence, Uneasy Silence Echo in Lahiri's 'Lowland"”. NPR. National Public Radio, 23 Sept. 2013. Web. 22 Aug. 2019

Das, Nigmanand. Jhumpa Lahir, Critical Perspectives, page 176, Pencraft International,2012 